\title{
The catechol-O-methyltransferase (COMT) inhibitor entacapone enhances the pharmacokinetic and clinical response to Sinemet CR in Parkinson's disease
}

Paola Piccini, David J Brooks, Kirsi Korpela, Nicola Pavese, Marianne Karlsson, Ariel Gordin

\begin{abstract}
Objectives-Entacapone is a specific, potent, peripherally acting catechol- $O$ methyltransferase (COMT) inhibitor. It has been shown to improve the bioavailability of plasma levodopa and extend its clinical effect when used as an adjunct to standard levodopa preparations, but there is little experience of the effect of entacapone on controlled release levodopa preparations.

Methods-A double blind, placebo controlled, single dose, randomised, cross over trial was performed in 14 patients with Parkinson's disease with motor fluctuations to investigate the clinical effect of a single dose of entacapone $(200 \mathrm{mg})$ when administered with either standard levodopa-carbidopa (Sinemet ${ }^{\mathrm{TM}}$ ) or controlled release levodopa-carbidopa preparations (Sinemet $\mathbf{C R}^{\mathrm{TM}}$ ).

Results-When entacapone was administered with standard Sinemet ${ }^{\mathrm{TM}}$ the duration of the clinical response to standard Sinemet ${ }^{\mathrm{TM}}$ was longer in comparison with the response after placebo $(p=0.02)$. Moreover, in the same patients, entacapone significantly increased the duration of the clinical response to Sinemet $\mathbf{C R}^{\mathrm{TM}}$ $(p=0.05)$ without prolonging the latency of response or enhancing dyskinesias.

Conclusions-These data confirm the clinical efficacy of entacapone-standard Sinemet ${ }^{\mathrm{TM}}$ combination. They also indicate that adding entacapone to controlled release levodopa preparations might provide a useful treatment option in patients with Parkinson's disease with motor fluctuations. A double blind clinical trial with a chronically administered entacaponeSinemet $\mathbf{C R}^{\mathrm{TM}}$ combination is, however, required to verify this viewpoint.

(F Neurol Neurosurg Psychiatry 2000;68:589-594)
\end{abstract}

Keywords: Parkinson's disease; entacapone; controlled release levodopa

Correspondence to:

Dr Paola Piccini, MRC

Cyclotron Unit,

Hammersmith Hospital, Du

Cane Road, W12 0NN

London, UK

paola.piccini@csc.mrc.ac.uk

Received 12 March 1999 and in revised form

10 November 1999

Accepted 26 November 1999
The combination of levodopa and a periphe ues to be the mainstay for the symptomatic ent Parkinson's disease. It provi stable and effective relief from symptoms and signs of the disease in most patients. Unfortunately, after several years of levodopa treatment fluctuations in the motor response appear and patients experience a wearing off of the antiparkinsonian effect at the end of each levodopa dose. About $30 \%$ of the patients treated with levodopa for 3 years can be expected to develop such "wearing off" effects. ${ }^{12}$ Subsequently the motor fluctuations become more complex and unpredictable. ${ }^{23}$

An important approach to the treatment of motor fluctuations and in particular the "wearing off" effect has been an attempt to prolong the elimination half life of levodopa in the plasma and so obtain more stable plasma levodopa concentrations. With this in mind, controlled release levodopa preparationsnamely levodopa-carbidopa (Sinemet $\mathrm{CR}^{\mathrm{TM}}$ ) and levodopa-benserazide (Madopar HBS ${ }^{\mathrm{TM}}$ ) - were developed in the late 1980s and early 1990s. Studies using these preparations have shown conflicting results, some reporting a significant clinical benefit when used as an adjunct with standard levodopa preparations and others finding no difference. ${ }^{4-8}$

Controlled release levodopa preparations have several drawbacks: their bioavailability is poorer and even more variable than with standard levodopa preparations, the dose of levodopa has, therefore, to be increased by about $30 \%$ to $50 \%$ compared with standard preparations. ${ }^{9}$ In addition, the derived clinical benefit, as measured by levodopa challenges, is not as long as might be expected. ${ }^{10}$

When DDC is inhibited, levodopa becomes peripherally inactivated via 3-O-methylation catalysed by cathecol- $O$-methyltransferase (COMT). Entacapone is a highly potent, selective, reversible, peripherally acting COMT inhibitor. ${ }^{11}{ }^{12}$ It is currently registered in EU countries in addition to being in further clinical trials. Entacapone does not have an intrinsic antiparkinsonian effect but, when it is used in combination with standard levodopa-DDC inhibitor formulations, it increases the bioavailability of levodopa by reducing its peripheral conversion to 3-O-methyldopa (3-OMD) ${ }^{11-13}$; this results in a prolongation of the therapeutic response to levodopa. In clinical studies entacapone as an adjunct to standard levodopa therapy has prolonged the "on" time of patients with fluctuating Parkinson's disease by 30 to 60 minutes compared with levodopa treatment alone. ${ }^{14-21}$

Most studies have been conducted using entacapone in association with standard levodopa-carbidopa formulations and there is 
Table 1 Demographic data of the patients and their history of Parkinson's disease

\begin{tabular}{llcccl}
\hline $\begin{array}{l}\text { Patient } \\
\text { No }\end{array}$ & Sex/age & $\begin{array}{c}\text { Duration of } \\
\text { symptoms }(y)\end{array}$ & $\begin{array}{l}\text { Duration of } \\
\text { levodopa } \\
\text { treatment }(y)\end{array}$ & $\begin{array}{l}\text { Duration of } \\
\text { fluctuations }(y)\end{array}$ & $\begin{array}{l}\text { Modified Hoehn } \\
\text { and Yahr stage }\end{array}$ \\
\hline 1 & $\mathrm{M} / 75$ & 8 & 5 & 2 & 2 \\
2 & $\mathrm{~F} / 70$ & 10 & 10 & 5 & 3 \\
3 & $\mathrm{~F} / 70$ & 4 & 4 & 1 & 3 \\
4 & $\mathrm{M} / 44$ & 2 & 1 & 1 & 2 \\
5 & $\mathrm{~F} / 62$ & 5 & 4 & 1 & 2.5 \\
6 & $\mathrm{~F} / 66$ & 14 & 14 & 10 & 4 \\
7 & $\mathrm{~F} / 77$ & 13 & 13 & 5 & 3 \\
8 & $\mathrm{M} / 71$ & 5 & 4 & 2 & 3 \\
9 & $\mathrm{~F} / 59$ & 3 & 2 & 1 & 3 \\
10 & $\mathrm{M} / 63$ & 7 & 6 & 4 & 3 \\
11 & $\mathrm{M} / 74$ & 7 & 7 & 4 & 3 \\
12 & $\mathrm{M} / 64$ & 12 & 11 & 4 & 2 \\
13 & $\mathrm{~F} / 75$ & 5 & 5 & 2 & 3 \\
14 & $\mathrm{M} / 65$ & 13 & 13 & 3 & 2 \\
15 & $\mathrm{M} / 75$ & 6 & 5 & 3 & 0.7 \\
Mean & 67.3 & 7.6 & 6.9 & 3.2 & \\
SD & 8.5 & 3.9 & 4.2 & 2.3 &
\end{tabular}

little experience of its effect with controlled release levodopa preparations. Theoretically, in patients with Parkinson's disease with "wearing off" fluctuations the combination of entacapone and controlled release levodopa should be even more beneficial than the combination of entacapone with standard levodopa. This is because there is more extensive degradation of levodopa into 3-OMD in the bowel with controlled release preparations. ${ }^{22}$ However, in one non-randomised open study, entacapone prolonged the "on" time to a similar extent with standard levodopa-carbidopa and controlled release levodopa-carbidopa. ${ }^{23}$

In this study we tested the clinical response to single doses of entacapone added to standard levodopa-carbidopa and controlled release levodopa-carbidopa formulations in patients with fluctuating Parkinson's disease, using a double blind, placebo controlled, randomised, cross over design.

\section{Methods}

PATIENTS

Fifteen patients with idiopathic Parkinson's disease and fluctuating motor responses to levodopa (wearing off) were studied. Seven of

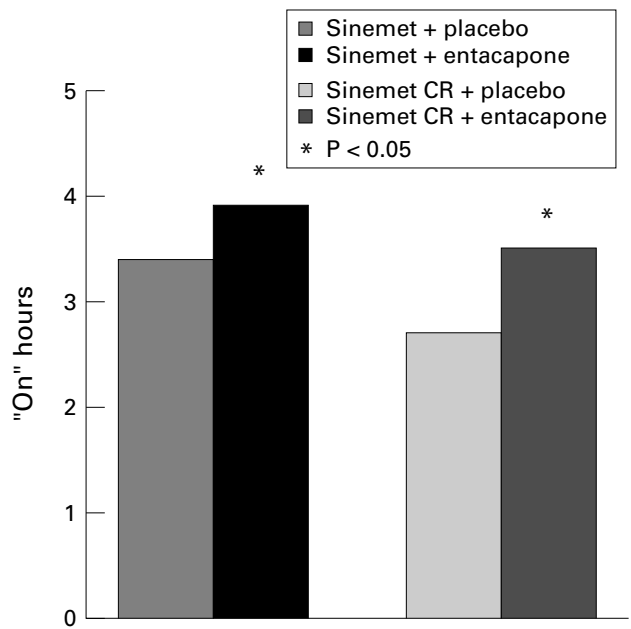

Figure 1 “On” time (20\% improvement from baseline UPDRS score) after administration of standard Sinemet ${ }^{\mathrm{TM}}$ (200 mg/50 mg) with or without a single dose of $200 \mathrm{mg}$ entacapone or Sinemet $C R^{\mathrm{TM}}(200 \mathrm{mg} / 50 \mathrm{mg}$ ) with and without a single dose of $200 \mathrm{mg}$ entacapone to 14 patients with Parkinson's disease (means). ${ }^{\star} p \leqslant 0.05$.

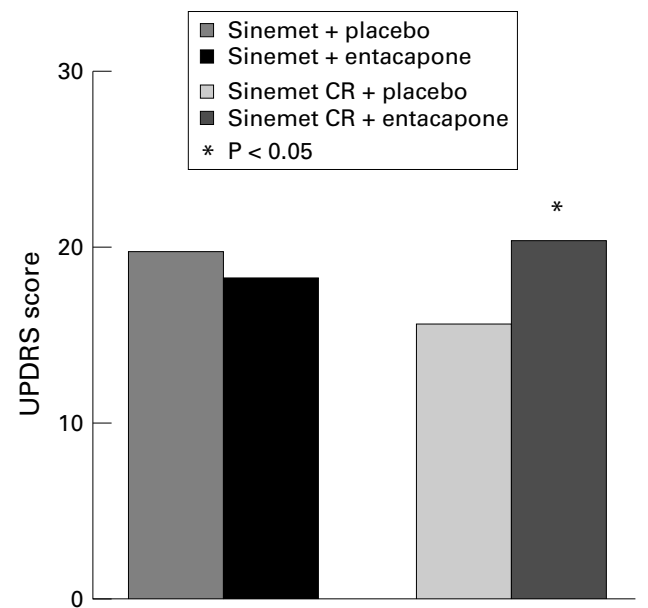

Figure 2 UPDRS maximal improvement after administration of standard Sinemet ${ }^{\mathrm{TM}}(200 \mathrm{mg} / 50 \mathrm{mg})$ with and without a single dose of $200 \mathrm{mg}$ entacapone, or Sinemet $C R^{\mathrm{TM}}(200 \mathrm{mg} / 50 \mathrm{mg})$ with or without a single dose of $200 \mathrm{mg}$ entacapone to 14 patients with Parkinson's disease (means). ${ }^{\star} p \leqslant 0.05$.

the 15 patients also experienced levodopa induced dyskinesias. Their demographic data are shown in table 1 . In addition to standard levodopa-carbidopa preparations, two patients were also taking dopamine agonists (pergolide; patient 7, bromocriptine; patient 11) and four were taking selegiline (patients $5,8,10$, and 15).

Only patients without psychiatric disorders or severe illnesses were included in the study. The study was conducted according to the principles of the Declaration of Helsinki and approved by the ethics committee of Hammersmith Hospital, London. All patients gave their signed consent after receiving verbal and written information about the study.

\section{STUDY DESIGN}

The study followed a double blind, randomised, placebo controlled, comparative cross over design over a 4 day period. On each test day the patients were administered one of

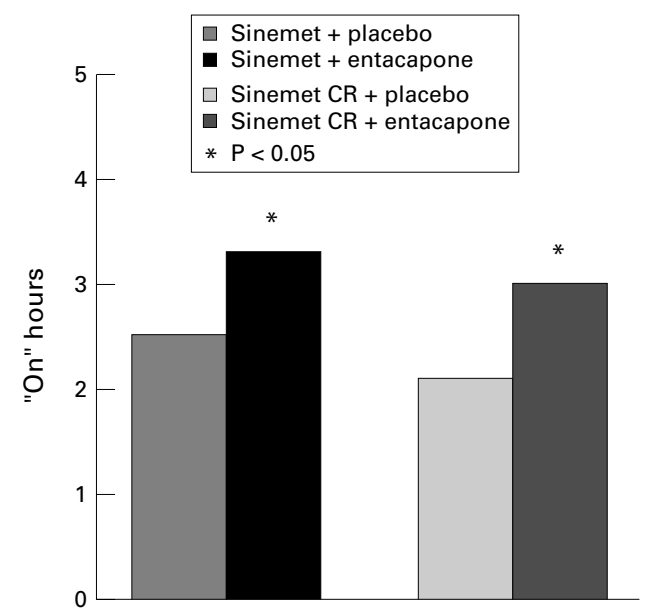

Figure 3 "On" time (20\% improvement on baseline tapping) after administration of standard Sinemet ${ }^{\mathrm{TM}}$ $(200 \mathrm{mg} / 50 \mathrm{mg}$ ) with or without a single dose of $200 \mathrm{mg}$ entacapone, or Sinemet $C R^{\mathrm{TM}}$ (200 $\mathrm{mg} / 50 \mathrm{mg}$ with or without a single dose of $200 \mathrm{mg}$ entacapone) to 14 patients with Parkinson's disease (means). ${ }^{\star} p \leqslant 0.05$. 


\begin{tabular}{|c|c|c|c|c|c|c|}
\hline & \multicolumn{3}{|c|}{ Standard Sinemet ${ }^{\mathrm{TM}}$} & \multicolumn{3}{|c|}{ Sinemet $C R^{\mathrm{TM}}$} \\
\hline & Placebo & Entacapone & $\Delta$ & Placebo & Entacapone & $\Delta$ \\
\hline "On" duration UPDRS score (h) & $3.4(0.9)$ & $3.9(1.2)$ & $0.50(0.22)^{\star}$ & $2.7(1.8)$ & $3.5(0.7)$ & $0.82(0.48)^{\star}$ \\
\hline "On" duration tapping test (h) & $2.5(1.2)$ & $3.3(1.5)$ & $0.82(0.32)^{\star}$ & $2.1(1.7)$ & $3.0(1.8)$ & $0.89(0.44)^{\star}$ \\
\hline Motor UPDRS improvement & $19.7(7.4)$ & $18.3(5.6)$ & $1.35(2.09)$ & $15.7(8.0)$ & $20.3(5.7)$ & $4.57(1.90)^{\star}$ \\
\hline Latency to "on" (h) & $1.2(0.4)$ & $1.4(0.4)$ & $0.21(0.14)$ & $1.7(0.6)$ & $2.0(0.9)$ & $0.21(0.26)$ \\
\hline Dyskinesias (magnitude) & $3.1(3.8)$ & $1.8(2.5)$ & $1.28(0.56)^{\star}$ & $2.2(4.5)$ & $2.4(4.0)$ & $0.21(0.09)$ \\
\hline Dyskinesias duration (h) & $1.2(1.5)$ & $1.0(1.4)$ & $0.21(0.23)$ & $0.6(1.2)$ & $0.9(1.6)$ & $0.25(0.45)$ \\
\hline
\end{tabular}

Values are presented as mean (SD),except $\Delta=$ mean differences (SE)

${ }^{\star} \mathrm{p} \leqslant 0.05$.

the following: a single dose of 200/50 mg levodopa-carbidopa (Sinemet ${ }^{\mathrm{TM}}$ ) and $200 \mathrm{mg}$ of entacapone; 200/50 mg Sinemet ${ }^{\mathrm{TM}}$ and placebo; 200/50 mg controlled release levodopacarbidopa (Sinemet CR ${ }^{\mathrm{TM}}$ ), or $200 \mathrm{mg}$ entacapone; $200 / 50 \mathrm{mg}$ Sinemet $\mathrm{CR}^{\mathrm{TM}}$ and placebo. Each patient was randomised to treatment sequences using replicated latin squares.

There was an interval of a week between each test day. During the interval the patients returned to taking their usual medications. All medications were stopped at least 6 hours before the test day.

On the test day the patients were given one of the four aforementioned drug combinations between 730 and $830 \mathrm{am}$; they had a low protein breakfast at 1030 am and lunch at $1230 \mathrm{pm}$.
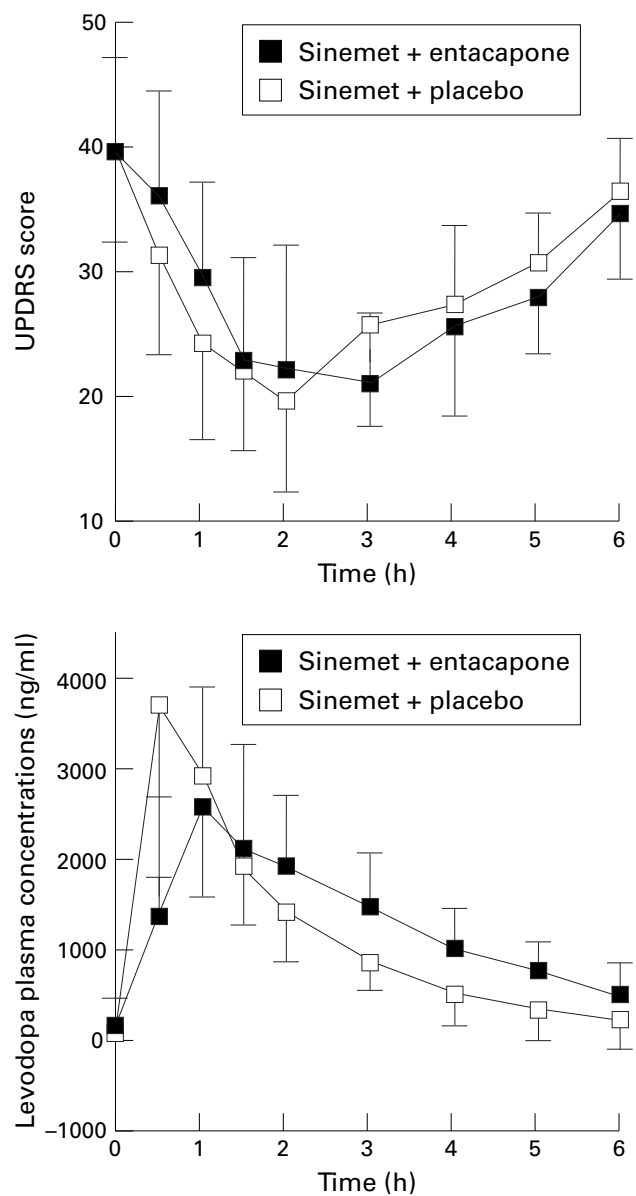

Figure 4 Time course of the UPDRS motor scores (14 patients) and levodopa plasma concentrations (12 patients) after standard Sinemet ${ }^{\mathrm{TM}}$ with and without entacapone (means (SD)).
CLINICAL RESPONSE ASSESSMENT AND EFFICACY INDICES

The clinical response on each test day was evaluated 30 and 15 minutes before and every 30 minutes for 6 hours after the intake of the drugs using the motor section (part III) of the unified Parkinson's disease rating scale (UPDRS) $^{24}$ supplemented with a dyskinesia score $^{25}$ and a tapping test.

The primary clinical efficacy variable was the duration of the motor response ("on" time). The patient was considered "on" when a $20 \%$ improvement from the baseline UPDRS and tapping scores (average of the scores obtained 15 and 30 minutes before the medications) was seen. The secondary efficacy variables were the UPDRS maximal improvement (maximal improvement from the baseline in UPDRS motor score), the latency to the motor response and the duration and severity of dyskinesias.

\section{PLASMA COLLECTION AND PHARMACOKINETIC} ANALYSIS

Venous blood samples for measurement of plasma concentrations of levodopa, its metabolites, and carbidopa and entacapone concentrations were collected 30 minutes before the intake of the medications and subsequently during the 6 hours that followed: every 30 minutes for the first 2 hours and, after that, every 60 minutes. The samples were protected from light during the handling and storing procedures. An ion pair reverse phase high pressure liquid chromatography (RP-HPLC) method with amperometric detection was used for determination of levodopa, 3-OMD, 3,4dihydroxyphenyl acetic acid (DOPAC), homovanillic acid (HVA), and carbidopa. ${ }^{26}$ Entacapone concentrations were measured by $\mathrm{RP}$-HPLC with amperometric detection. ${ }^{27}$ The maximum plasma peak concentration (Cmax), the time of maximum concentration (Tmax) of levodopa, carbidopa, and entacapone were determined according to standard methods as described previously. ${ }^{28}$ The area under the plasma concentration time curve (AUC) was calculated by the linear trapezoidal method ${ }^{29}$ from zero to the last detectable concentration (AUC) for levodopa, carbidopa, DOPAC, 3-OMD, and HVA.

STATISTICAL METHOD

Statistical analysis of clinical and pharmacokinetic variables comparing the effects of entacapone on Sinemet ${ }^{\mathrm{TM}}$ and Sinemet $\mathrm{CR}^{\mathrm{TM}}$ were performed with a paired Wilcoxon test. 

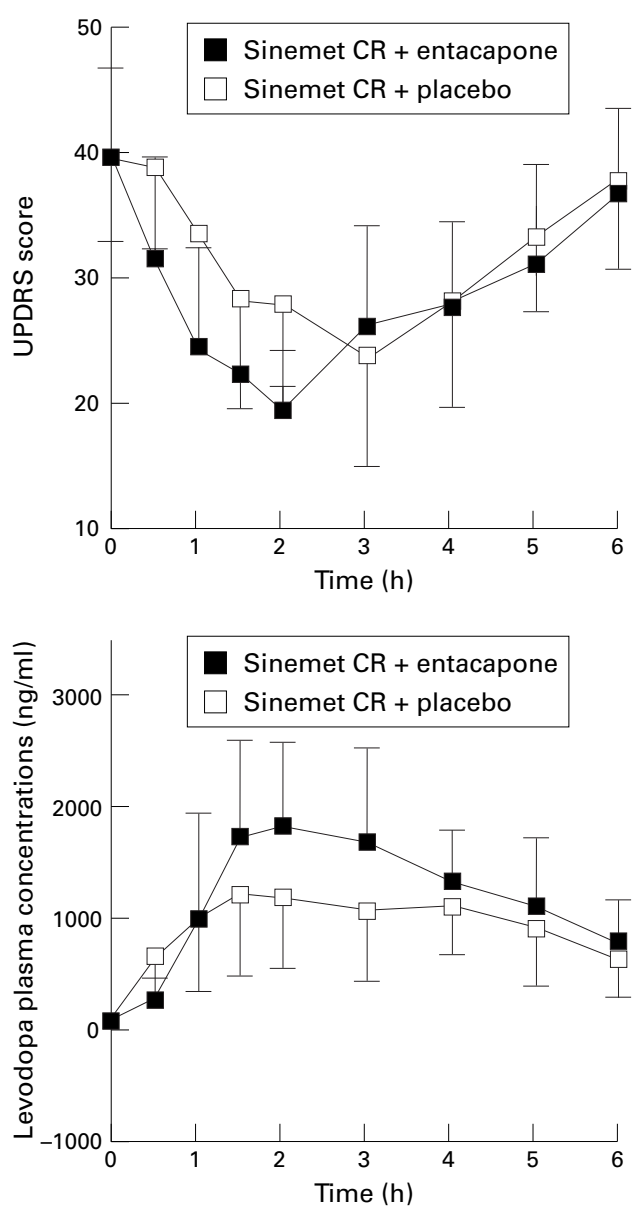

Figure 5 Time course of the UPDRS motor scores (14 patients) and levodopa plasma concentrations (12 patients) after Sinemet $C R^{\mathrm{TM}}$ with and without entacapone (means $(S D))$.

\section{Results}

All 15 patients completed the protocol as outlined. A few months after the end of the study, one of the patients (patient 15, table 1) developed prominent signs of autonomic failure and mild cerebellar ataxia. This patient was rediagnosed as having multiple system atrophy and his data were excluded from subsequent analyses.

Plasma samples from two other patients were lost in transit to the central laboratory and so only 12 patients had pharmacokinetic analyses.
CLINICAL RESULTS

The duration of "on" time was prolonged when entacapone was administered with both standard Sinemet ${ }^{\mathrm{TM}}$ (30 minute increase, $\mathrm{p}=0.03$ ) and Sinemet $\mathrm{CR}^{\mathrm{TM}}$ (48 minute increase, $\mathrm{p}=0.05)$ in comparison with the responses when placebo was added (fig 1).

The UPDRS maximal improvement was greater when entacapone was given with Sinemet $\mathrm{CR}^{\mathrm{TM}}(\mathrm{p}=0.02)$ but not with standard Sinemet ${ }^{\mathrm{TM}}$. After Sinemet $\mathrm{CR}^{\mathrm{TM}}$ with placebo the UPDRS maximal improvement was smaller compared with standard Sinemet ${ }^{\mathrm{TM}}$ with placebo but the difference was not significant (fig 2).

The latency of the motor response was not significantly affected by adding entacapone to levodopa; an increase of 0.2 hours with standard Sinemet ${ }^{\mathrm{TM}}$ and 0.3 hours with Sinemet $\mathrm{CR}^{\mathrm{TM}}$ was noted $(\mathrm{p}=0.21$ and $\mathrm{p}=0.31$, respectively).

The duration of "on" time assessed with a tapping test was also longer when entacapone was administered with either standard Sinemet ${ }^{\mathrm{TM}}$ (48 minutes increase, $\mathrm{p}=0.01$ ) or Sinemet $\mathrm{CR}^{\mathrm{TM}}$ (54 minutes increase, $\mathrm{p}=0.03$ ) in comparison with the responses obtained after addition of placebo (figure 3).

Eight of the 14 patients had dyskinesias after administration of standard Sinemet ${ }^{\mathrm{TM}}$ with placebo and four had dyskinesias after Sinemet $\mathrm{CR}^{\mathrm{TM}}$ with placebo. In these patients the addition of entacapone to Sinemet $\mathrm{CR}^{\mathrm{TM}}$ did not increase the severity $(p=0.50)$ or duration $(\mathrm{p}=0.34)$ of dyskinesias. The addition of entacapone to standard Sinemet ${ }^{\mathrm{TM}}$ reduced the severity $(p=0.02)$, but not the duration of dyskinesias $(p=0.19)$. These clinical results are summarised in table 2 .

Figures 4 and 5 show the time course of the UPDRS motor scores and levodopa plasma concentrations after standard Sinemet ${ }^{\mathrm{TM}}$ (fig 4) and Sinemet CR ${ }^{\mathrm{TM}}$ (fig 5), both with and without entacapone.

\section{PHARMACOKINETICS}

Parmacokinetic indices of levodopa, its metabolites, carbidopa, and entacapone are summarised in table 3. Briefly, when $200 \mathrm{mg}$ entacapone was added to standard Sinemet ${ }^{\mathrm{TM}}$, the mean area under the curve (AUC) values of levodopa increased by $10 \%$ compared with placebo. This change did not, however, reach significance $(\mathrm{p}=0.15)$. The Cmax of levodopa

Table 3 Pharmacokinetic data (12 patients)

\begin{tabular}{|c|c|c|c|c|c|c|}
\hline & \multicolumn{3}{|c|}{ Standard Sinemet $\mathrm{T}^{\mathrm{TM}}$} & \multicolumn{3}{|l|}{ Sinemet $C R^{\mathrm{TM}}$} \\
\hline & Placebo & Entacapone & $\Delta$ & Placebo & Entacapone & $\Delta$ \\
\hline Levodopa AUC (h×ng/mg) & $7025(2068)$ & $7757(3475)$ & $732(796)$ & $5390(1818)$ & $6941(3009)$ & $1550(583)^{\star \star}$ \\
\hline Levodopa Cmax $(\mathrm{ng} / \mathrm{ml})$ & $4144(1681)$ & $3091(1560)$ & $1107(525)^{\star}$ & $1739(663)$ & $2270(902)$ & $\left(0.505(207)^{\star}\right.$ \\
\hline Levodopa Tmax (h) & $0.66(7.5)$ & $1.29(0.7)$ & $0.62(0.21)^{\star \star}$ & $2.25(1.5)$ & $2.66(1.4)$ & $\left(0.41(0.39)^{\star}\right.$ \\
\hline 3-OMD AUC (h×ng/mg) & $43670(20304)$ & $33241(19380)$ & $10428(4080)^{\star \star}$ & 40055 (2493) & $36840(25454)$ & (3215 (1855) \\
\hline DOPAC AUC (h×ng/mg) & $338(201)$ & $816(377)$ & $477(75)^{\star}$ & $243(160)$ & $628(328)$ & $\left(438(100)^{\star}\right.$ \\
\hline Carbidopa AUC (h×ng/mg) & $860(518)$ & $714(492)$ & $145(58)^{\star}$ & $507(366)$ & $587(338)$ & $(80(71)$ \\
\hline Carbidopa Cmax (ng/ml) & $212(111)$ & $169(108)$ & $43(14)^{\star}$ & $124(84)$ & $150(77)$ & $(25(21)$ \\
\hline Carbidopa Tmax (h) & $1.9(0.8)$ & $3(1)$ & $1(0.3)^{\star}$ & $4(1.2)$ & $4(1.1)$ & $(0(0.3)$ \\
\hline Entacapone AUC (h×ng/mg) & & $1799(933)$ & & & $2121(739)$ & \\
\hline Entacapone Cmax (ng/ml) & & $1555(1597)$ & & & $1951(1063)$ & \\
\hline
\end{tabular}

Values are presented as mean (SD), except $\Delta=$ mean (SE).

${ }^{\star} \mathrm{p} \leqslant 0.05 ;{ }^{\star \star} \mathrm{p} \leqslant 0.01$. 
decreased by $25 \%(p=0.05)$ and the Tmax doubled $(\mathrm{p}=0.01)$.

When $200 \mathrm{mg}$ entacapone was added to the Sinemet $\mathrm{CR}^{\mathrm{TM}}$ treatment, the mean increase in the AUC of levodopa was $22 \%(\mathrm{p}=0.01)$ compared with placebo. Entacapone also increased the Cmax by $28 \%(p=0.02)$ and the Tmax of levodopa non-significantly by $18 \%$.

\section{Discussion}

The present study confirms and extends the previously reported findings that entacapone enhances the clinical efficacy of both standard and controlled release levodopa-carbidopa preparations. When added to a standard levodopa-carbidopa preparation, entacapone significantly increased the duration of the clinical response by 30 minutes without prolonging the latency of response in our patients. A mild decrease in dyskinesia magnitude, but not in dyskinesia duration, was also seen. These findings confirm the reported clinical efficacy of entacapone in reducing "off" time and increasing "on" time in patients with Parkinson's disease and motor fluctuations. ${ }^{14-21}$

The functional effects of entacapone treatment have also been elegantly demonstrated with ${ }^{18} \mathrm{~F}$-6-fluorodopa positron emission tomography (PET), a $400 \mathrm{mg}$ oral dose increasing striatal levodopa storage by $40 \%$ in patients with early Parkinson's disease. ${ }^{29-31}$

To date, there has been little reported experience of the effect of entacapone on controlled release levodopa preparations. A pharmacological interaction study of entacapone and controlled release levodopa-carbidopa in healthy volunteers ${ }^{32}$ showed that entacapone increased the AUC of levodopa and the Cmax, but did not influence the Tmax. Similar results were observed when tolcapone, another COMT inhibitor, was combined with a levodopa-benserazide formulation. ${ }^{33}$ Kaakkola et $a l^{23}$ have investigated the clinical and pharmacokinetic responses to levodopa when entacapone was administered concomitantly with either a standard or a controlled release levodopa-carbidopa preparation in patients with Parkinson's disease. Results from this short term open cross over study suggested that entacapone improved the clinical response to the controlled release levodopa preparation.

Our study is the first one conducted in a double blind placebo controlled randomised fashion. Entacapone, added to controlled release levodopa-carbidopa (Sinemet $\mathrm{CR}^{\mathrm{TM}}$ ) was significantly more effective than placebo in prolonging the duration of "on" time assessed using both the motor section (III) of the UPDRS and a tapping test. The maximal improvement of the motor response was also increased when entacapone was added to Sinemet CR ${ }^{\mathrm{TM}}$. The duration of the "on" time was less prolonged than in the previous open study by Kaakkola et $a .^{23}$ This could be due to the fact that we considered patients to be "on" when the UPDRS and tapping test score were improved by $\geqslant 20 \%$ from the baseline score. When using Kaakkola's 10\% improvement criterion for "on", the duration of "on" time after entacapone was longer than the 6 hour test period in some of our patients. The latencies to the onset of motor response and the magnitude and duration of dyskinesias were not affected by entacapone.

Pharmacokinetic results mirrored the clinical results: the AUC of levodopa was significantly increased after addition of entacapone compared with placebo. Entacapone also increased the Cmax and the Tmax of levodopa when given with Sinemet $\mathrm{CR}^{\mathrm{TM}}$.

These results, obtained after single doses of entacapone, indicate that the chronic addition of this drug to controlled release levodopa preparations could be a useful treatment strategy in Parkinson's disease patients with motor fluctuations. A double blind long-term treatment study is warranted to confirm this view point.

Moreover, there are indications that combination entacapone plus controlled release levodopa formulations could be useful in patients with Parkinson's disease in the early stages of disease. Chronic intermittent stimulation of dopaminergic receptors, such as occurs with conventional multiple daily standard levodopa treatments, may induce D1 and D2 receptor down regulation ${ }^{34-37}$ and modify the release and the striatal metabolism of dopamine. ${ }^{38}$ Such changes could be important in the pathogenesis of motor fluctuations. Therefore, any possible smoothing of the intermittent pulsatile nature of short levodopa preparations lending to a more sustained striatal response should in theory be adopted from the earliest stages of Parkinson's disease. Controlled release preparations of levodopa cannot be expected to produce plasma levodopa profiles comparable to continuous infusion, nevertheless, compared to standard preparations, they provide somewhat more stable plasma levodopa concentrations ${ }^{9}$ with significantly fewer doses each day. ${ }^{5}$ We suggest that the use of controlled release levodopa preparations in combination with entacapone is a further option for better controlling the administration and elimination of levodopa to produce a truly uniform pharmacokinetic and clinical response and could be used in patients with early Parkinson's disease without motor fluctuations.

1 Marsden CD, Parkes JD. Success and problems of long-term evodopa therapy in Parkinson's disease. Lancet 1977;i:345-9.

2 Hardie RJ, Lees AJ, Stern GM. On-off fluctuations in Parkinson's disease: a clinical and neuropharmacological study. Brain 1984;107:487-509.

3 Fabbrini G, Juncos J, Mouradian M, et al. Levodopa pharmacokinetics and motor fluctuations in Parkinson's pharmacokinetics and motor fluctuat

4 Pahwa R, Lyons K, McGuire D, et al. Comparison of standard carbidopa-levodopa and sustained-release carbidopa levodopa in Parkinson's disease: pharmacokinetic and quality-of-life measures. Mov Disord 1997;12:677-81

5 Hutton J, Morris J. Therapeutic advantages of sustained release levodopa formulations. CNS Drugs 1994;2:110-19.

6 Koller W, Pahwa R. Treating motor fluctuations with controlled-release levodopa preparations. Neurology 1994; 44(suppl 6):S23-8.

7 LeWitt P. Clinical studies with and pharmacokinetic considerations of sustained-release levodopa. Neurology 1992;42(suppl 1):29-32.

8 Graham J, Henderson J, Morris J, et al. Comparison of standard Madopar and controlled release Madopar in Parkinson's disease. Aust NZ ¥ Med 1991;21:11-15.

9 Yeh KC, August TF, Bush DF, et al. Pharmacokitetics and bioavailability of Sinemet CRT: a summary of human bioavailability of Sinemet CR
studies. Neurology 1989;39:25-38.

10 Marion MH, Stocchi F, Malcolm SL, et al. Single-dose studies of a slow-release preparation of levodopa and 
benserazide (Madopar HBS) in Parkinson's disease. European Neurology 1994;27(suppl 1):54-8.

11 Nissinen E, Linden IB, Schultz E, et al. Biochemical and pharmacological properties of a peripherally acting catechol- $O$-methyltransferase Naunyn-Schmieddberg's Archives of Pharmacology 1992;346 $262-6$

12 Kaakkola S, Wurtman RJ. Effects of COMT inhibitors on striatal dopamine metabolism: a microdialysis study. Brain Res 1992;587:241-9.

13 Keränen T, Gordin A, Harjola VP, et al. The effect of catechol-O-methyl transferase inhibition by entacapone on the pharmacokinetics and metabolism of levodopa in healthy volunteers. Clin Neuropharmacol 1993;16:145-56.

14 Myllylä VV, Sotaniemi KA, Illi A, et al. Effect of entacapone, a COMT inhibitor, on the pharmacokinetics of levodopa and on cardiovascular responses in patients with Parkinson's disease. Eur 7 Clin Pharmacol 1993;45:419-23.

15 Kaakkola S, Teräväinen $\mathrm{H}$, Ahtila S, et al. Effect of entacapone, a COMT inhibitor, on clinical disability and levodopa metabolism in parkinsonian patients. Neurology 1994:44:77-80.

16 Merello M, Lees AJ, Webster R, et al. Effect of entacapone, a peripherally acting catechol-O-methyl transferase inhibitor, on the motor response to acute treatment with levodopa in patients with Parkinson's disease. I Neurol Neurosurg Psychyiatry 1994;57:186-9.

17 Nutt JG, Woodward WR, Beckner RM, et al. Effect of peripheral catechol- $O$-methyl transferase inhibition, on the pharmacokinetics and pharmacodynamics of levodopa in parkinsonian patients. Neurology 1994;44:913-19.

18 Ruottinen HM, Rinne UK. A double-blind pharmacokinetic and clinical dose-response study of entacapone as an adjunct to levodopa therapy in advanced Parkinson's disease. Clin Neuropharmacol 1996;19:283-96.

19 Ruottinen HM, Rinne UK. Effect of one month's treatment with peripherally acting catechol-O-methyltransferase inhibitor, entacapone, on pharmacokinetics and motor hibitor, entacapone, on pharmacokinetics and motor response to levodopa in advanced park
Clin Neuropharmacol 1996;19:222-33.

20 Ruottinen HM, Rinne UK. Entacapone prolongs levodopa response in a one month's double blind study in parkinsonian patients with levodopa related fluctuations. F Neurol Neurosurg Psychiatry 1996;60:36-40

21 Rinne UK, Larsen JP, Siden A, et al. Entacapone enhances the response to levodopa in Parkinson patients with moto fluctuations. Nomecomt Study Group. Neurology 1998;51: 1309-14

22 Cedarbaum JM, Lyn Breck RN, Kutt H, et al. Controlledrelease levodopa/carbidopa. II Sinemet $\mathrm{CR}^{\mathrm{TM}} 4$ treatment of response fluctuations in Parkinson's disease. Neurology 1987;37:1607-12.

23 Kaakkola S, Teräväinen $\mathrm{H}$, Ahtila S, et al. Entacapone in combination with standard or controlled-release levodopacarbidopa: a clinical and pharmacokinetic study in patients carbidopa: a clinical and pharmacokinetic study in parie

24 Fahn S, Elton RL, Members of the UPDRS Development Committee. Unified Parkinson's disease rating scale. In:
Fahn S, Marsden CD, Calne D, et al, eds. Recent developments in Parkinson's disease. Vol 2. Florham Park: Macmillan Helthcare Information, 1987:153-63.

25 Esteguy M., Bonnet AM, Kefalos J, et al. Le test a la L-Dopa dans la maldie de Parkinson. Rev Neurol (Paris) 1985:141: 413-415.

26 Wikberg T. Simultaneous determination of levodopa, its main metabolites and carbidopa in plasma by liquid chromatography. F Pharm Biomed Anal 1991;9:167-76.

27 Karlsson M, Wikberg T. Liquid chromatographic determination of a new catechol-O-methyltransferase inhibitor, entacapone, and its Z-isomer in human plasma and urine. f Pharm Biomed Anal 1992;10:593-600.

28 Gibaldi M, Perrier D. Pharmacokinetics. 2nd ed. Marcel Dekker, New York, 1982.

29 Sawle GV, Burn DJ, Morrish PK, et al. The effect of entacapone (OR-611) on brain ${ }^{18} \mathrm{~F}$-6-fluorodopa metabolism: implications for levodopa therapy of Parkinson's disease. Neurology 1994;44:1292-7.

30 Ruottinen HM, Rinne JO, Ruotsalainen UH, et al. Striatal F-fluorodopa utilisation after COMT inhibition with entacapone studied with PET in advanced Parkinson's disease. 7 Neural Transm Park Dis Dement Sect 1995;10:91-106.

31 Ishikawa T, Dhawan V, Chaly T, et al. Fluorodopa positron emission tomography with an inhibitor of catechol-Omethyltransferase: effect of the plasma 3-O-methyldopa fraction on data analysis. F Cereb Blood Flow Metab 1996;16:854-63.

32 Ahtila S, Kaakkola S, Gordin A, et al. Effect of entacapone, a COMT inhibitor, on the pharmacokinetics and metabolism of levodopa after administration of controlled-release levodopa-carbidopa in volunteers. Clin Neuropharmacol 1995;18:46-57.

33 Jorga K, Fotteler B, Schmitt M, et al. Effect of COMT inhibition by tolcapone on tolerability and pharmacokinetics of different levodopa-benserazide formulations. Eur Neurol 1997;38:59-67.

34 Friedhoff AJ, Bonnet K, Rosengarten $\mathrm{H}$. Reversal of two manifestations of dopamine receptor supersensitivity by administration of levodopa. Research Communications in Chemical Patology and Pharmacology 1977;16:411-23.

35 Reches A, Wagner HR, Jackson-Lewis V, et al. Chronic levodopa or pergolide administration induces down regulation of dopamine receptors in denervated striatum. Neurology 1994;34:1208-12.

36 Brooks DJ, Ibanez V, Sawle GV, et al. Striatal D2 receptors status in patients with PD striatonigral degeneration, and progressive supranuclear palsy, measured with ${ }^{11} \mathrm{C}$ raclopride and positron emission tomography. Ann Neurol 1992;31:184-92.

37 Turjanski N, Lees AJ, Brooks DJ. In vivo studies on striatal dopamine D1 and D2 site binding in L-dopa-treated Parkinson's disease patients with and without dyskinesias. Neurology 1997;49:717-23.

38 Brannan T, Martinez-Tica J, Yahr MD. Effect of long term L-dopa administration on striatal extracellular dopamine release. Neurology 1981;41:2596-8. 